\title{
SPRAWIEDLIWOŚĆ EDUKACYJNA JAKO KATEGORIA FILOZOFII KSZTAŁCENIA
}

\begin{abstract}
Streszczenie: W artykule przedstawiam najpierw pogląd, że rekonstrukcja sprawiedliwości edukacyjnej jest możliwa tylko pod warunkiem przeprowadzenia jej w obszarze filozofii kształcenia. W drugiej części przeprowadzam taką rekonstrukcję. Jej wynik można podsumować w następujący sposób: błędem jest interpretowanie sprawiedliwości edukacyjnej jako sprawiedliwości w sferze osiągnięć i/lub zdolności uczniów. Nie można również twierdzić, że jest ona rodzajem sprawiedliwości dystrybutywnej, w której zasadą jest równy podział środków materialnych i szans edukacyjnych. Sprawiedliwość edukacyjną należy raczej rozumieć jako swoisty rodzaj relacji. Zgodnie z tym instytucje edukacyjne i interakcje pedagogiczne są sprawiedliwe tylko wówczas, gdy ucieleśniają w sobie trzy formy uznania: empatię, respekt moralny i szacunek społeczny. Twierdzenie to staje się jeszcze bardziej oczywiste, jeżeli nawiąże się do niedawnej dyskusji filozoficznej na temat epistemic justice.
\end{abstract}

Słowa kluczowe: sprawiedliwość edukacyjna, filozofia kształcenia, empatia, respekt moralny, szacunek społeczny

W dyskursie oświatowo-politycznym kategoria sprawiedliwości edukacyjnej (niem. Bildungsgerechtigkeit) jest obecnie bardzo popularna. Szczególnie wyraźnie widać to w Niemczech, ale chyba nie tylko. Tym bardziej musi więc dziwić fakt, że do tej pory nie została ona poddana wnikliwej analizie pojęciowej, a jej zawartość znaczeniowa nie była przedmiotem systematycznych rekonstrukcji historycznych i analitycznych. Istotnym powodem takiego stanu rzeczy może być to, że analizy pojęciowe i systematyczne rekonstrukcje semantyczne stanowią „ciało obce” w strukturze współczesnej nauki o wychowaniu, której w niemieckim obszarze językowym często przyznaje się prawo do wyłączności, jeżeli chodzi o wyjaśnianie procesów kształcenia.

W pierwszej części tego artykułu bardziej szczegółowo wyjaśniam zasygnalizowany deficyt w pedagogicznych rozważaniach nad sprawiedliwością edukacyjną. Robię to po to, aby w kolejnej części wykazać, że uda się go zniwelować tylko wtedy, gdy omawianą kategorię potraktuje się jako należącą do filozofii kształcenia - a nie 
wyłącznie do nauki o wychowaniu. Rozdział trzeci i czwarty są poświęcone rekonstrukcji najbardziej charakterystycznych cech kategorii sprawiedliwości edukacyjnej i normatywnym implikacjom, które z niej wynikają. W tym celu oddzielam najpierw tę kategorię od spokrewnionej z nią sprawiedliwości zdolności i osiągnięć, a następnie stawiam tezę, że sprawiedliwości edukacyjnej nie należy odczytywać jako specyficznego rodzaju sprawiedliwości rozdzielczej, lecz wyłącznie jako sprawiedliwość polegającą na uznaniu drugiego człowieka w jego osobowej godności (niem. Anerkennungsgerechtigkeit). W ostatniej części artykułu to rozumienie sprawiedliwości edukacyjnej zostaje wyjaśnione przez odwołanie do toczącej się od kilku lat międzynarodowej dyskusji wokół pojęcia epistemic injustice, które moim zdaniem można zinterpretować jako niesprawiedliwość edukacyjną wynikającą $\mathrm{z}$ braku lub niedostatecznego uznania drugiej osoby.

\section{Rozbieżność między interesem publicznym odnośnie do sprawiedliwości edukacyjnej a stanem analiz tego pojęcia}

Przed kilkoma laty Peter J. Brenner trafnie zauważył, że chociaż pojęcie sprawiedliwości edukacyjnej wkrótce po ogłoszeniu wyników badań PISA w 2000 roku zawładnęło debatą polityczną w Niemczech, to jednak w naukach o wychowaniu i kształceniu - jak do tej pory - nie dokonano szczegółowego dookreślenia go jako kategorii naukowej (Brenner 2009, s. 29). W prowadzonej swego czasu dyskusji na temat wyników PISA trzeba właściwie uznać za rodzaj skandalu to, że zaniedbano problematyzacji tego pojęcia, nie mówiąc już o jego wyjaśnieniu. Sprawiedliwość systemu oświatowego była w niej ukazywana prawie wyłącznie jako kwestia zależności osiągnięć edukacyjnych i związanych z nimi karier zawodowych uczniów od ich pochodzenia społeczno-kulturowego. Nie zapytano natomiast w ogóle o to, dlaczego i w jakim stopniu uzależnienie procesów kształcenia od pochodzenia społeczno-kulturowego jest przyczyną niesprawiedliwości edukacyjnej oraz czy istnieją w niemieckim systemie oświaty inne jeszcze formy tej niesprawiedliwości (tamże, s. 34).

Powyższa ocena prowadzonej wówczas dyskusji jest nadal aktualna. Ten sam deficyt ujawnia się również w nowszych studiach. Co prawda w najnowszym narodowym raporcie na temat wyników badania PISA, który został ogłoszony w 2012 roku, termin „sprawiedliwość edukacyjna” (odpowiadający „równości szans") jest używany z dużą ostrożnością, jednak bez jakiejkolwiek (choćby tylko zalążkowej) analizy systematycznej. Jego autorzy zadowalają się enigmatycznie sformułowanym wskazaniem na stan odnośnej dyskusji w ramach teorii sprawiedliwości. Zdaniem niektórych badaczy we wspomnianej publikacji termin „sprawiedliwość edukacyjna” jest tożsamy po prostu z equity (Müller, Ehmke 2013, s. 245). Poza tym jej autorzy całkowicie ignorują fakt, że istnieje cały szereg znanych i uznanych koncepcji sprawiedliwości nieegalitarnej i że w międzynarodowej dyskusji odnośnie do kategorii sprawiedliwości rozważa się rozmaite odmiany 
egalitaryzmu i różne formy equity. Niektóre z tych odmian i form zostaną omówione w dalszej części artykułu.

Wskazane powyżej w znacznej mierze zaniedbane zadanie systematycznej i możliwie wszechstronnej analizy kategorii sprawiedliwości edukacyjnej w ramach skoncentrowanej przede wszystkim na empirycznych badaniach terenowych nauce o wychowaniu i dynamicznie rozwijającej się w niej dziedzinie badań edukacyjnych staje się jeszcze bardziej doniosłe i politycznie niecierpiące zwłoki, gdy uzmysłowimy sobie specyfikę epistemologicznego charakteru tej kategorii.

"Sprawiedliwość" w ogólności, a „sprawiedliwość edukacyjna” jako jej specyficzny przypadek, należą do kategorii terminów o silnym ładunku ideologicznym (Göhler i in. 2004). W nomenklaturze anglo-amerykańskiej opatruje się je uwagą essentially contested concepts (Gallie 1964, s. 157-191). Terminy te wywołują zazwyczaj pełne emocjonalnego napięcia kontrowersje, gdyż służą nie tylko do systematyzującego opisu pewnych stanów rzeczy, lecz również do bezpośredniego wartościowania związanych z nimi praktyk politycznych. Innymi słowy pojęciom tym towarzyszy nieodłączna treść normatywna i działanie na korzyść lub niekorzyść obiektów należących do zakresu ich denotacji. Wynika z tego wprost wniosek, że w dyskusjach toczących się wokół tych pojęć do rzeczowych argumentów dołącza się z reguły ideologicznie zabarwione figury retoryczne, za którymi skrywają się grupy interesów wraz z prowadzonymi przez nie „grami”. Przykładowo w tym właśnie sensie niektórzy aktorzy niemieckiej sceny politycznej przedstawiają sprawiedliwość edukacyjną jako „sprawiedliwość uzdolnień”, mimo że taka interpretacja - jak wyjaśnię poniżej - nie ma żadnego odzwierciedlenia w rzeczywistości, o którą tutaj chodzi. Posługujący się nią politycy wykorzystują termin „sprawiedliwość edukacyjna" jako parawan dla utrzymania wysoce selektywnego, trójwarstwowego systemu szkolnego w Niemczech, w którym klientela wątpliwych stowarzyszeń i polityków cieszy się dużymi przywilejami (Stojanov 2011, s. 119).

\section{Sprawiedliwość edukacyjna jako domena filozofii kształcenia}

Głównego powodu opisanej powyżej rozbieżności między stopniem społecznego zainteresowania sprawiedliwością edukacyjną a niezadowalającym stanem jej analitycznego zgłębienia należy doszukiwać się przede wszystkim w tym, że do niedawna w niemieckojęzycznym obszarze językowym postulowano powierzenie obszaru badawczego obejmującego system oświatowy (włącznie z pytaniami i problemami sprawiedliwości edukacyjnej) nauce o wychowaniu, jednak dyscyplina ta - z powodu swojego ukierunkowania epistemologicznego - nie była w stanie bezstronnie przeprowadzić systematycznej i analitycznej rekonstrukcji normatywnie naładowanych terminów teorii kształcenia. Podobnie ma się rzecz z najmłodszym działem badań edukacyjnych, który pozbawia tradycyjnie rozumianą naukę o wychowaniu jej dominującej pozycji w badaniach pedagogicznych i zawłaszcza problematykę kształcenia wyłącznie dla siebie. Również tutaj mamy do czynienia z niemożnością 
sprostania wskazanemu zadaniu, która nie wynika bynajmniej z uwarunkowań zewnętrznych, lecz z wewnętrznej struktury owego działu.

Na przełomie lat 6o. i 7o. XX wieku Wolfgang Brezinka ukuł formułę: „od pedagogiki do nauki o wychowaniu", która nie tylko wyrażała w skrócie zmianę paradygmatyczną, jaka dokonała się w tamtym okresie w niemieckiej refleksji pedagogicznej, lecz również ustalała na przyszłe dziesięciolecia najwłaściwszy sposób badania fenomenów wychowania i kształcenia (Brezinka 1968). Według niego (nowa) nauka o wychowaniu powinna odgraniczyć się od (starej) pedagogiki humanistycznej (niem. geisteswissenschaftliche Pädagogik) przede wszystkim poprzez przyjęcie zdecydowanie nienormatywnej orientacji. Zgodnie z tym rozumowaniem w (prawdziwej) nauce nie wolno dokonywać jakichkolwiek wartościowań ani formułować czy uzasadniać normatywnych zasad działania. Postępowanie naukowe powinno się raczej ograniczyć do formułowania zdań opisowych, które można poddawać empirycznej falsyfikacji (tamże, s. 441).

Powyższa postawa miała doprowadzić do odrzucenia wszystkich terminów nacechowanych normatywnie. Proces ten Brezinka przedstawił na przykładzie terminu „kształcenie” (tamże, s. 444). W późniejszych latach można go było z łatwością obserwować we wszystkich obszarach nauki o wychowaniu i odnośnie do różnych pojęć, nie wyłączając wspomnianej powyżej kategorii sprawiedliwości ${ }^{1}$.

Jednym $z$ katastrofalnych skutków takiego rozumienia nauki było to, że analizy pojęciowe zostały z góry zepchnięte na margines zainteresowań „nowej” nauki o wychowaniu. Kategorie, którymi na co dzień posługiwano się przy wymianie myśli, rzadko poddawano krytyce, jeśli chodzi o ich znaczenie, albo nie robiono tego w ogóle. Wskutek tego były one często definiowane w sposób arbitralny, to jest bez poddawania ich systematycznej rekonstrukcji czy konfrontacji z rzeczową argumentacją pochodzącą z przyjęcia innych punktów widzenia (Paschen, Wigger 1992, s. 61-65). Nie powinno to właściwie nikogo dziwić, zwłaszcza jeżeli uwzględni się fakt, że istnieje ścisły związek między rozwojem analitycznych badań pojęciowych a ich wykorzystaniem przy tworzeniu nowych koncepcji teoretycznych. Badania te rozwijają się przede wszystkim w ramach normatywnych podejść badawczych, które mogą uchodzić za całkowicie uprawnione co najmniej od ukazania się po raz pierwszy w 1971 roku dzieła Johna Rawlsa pt. Teoria sprawiedliwości, przy czym rehabilitacja ich dokonała się - o ironio! - w tym samym czasie, w którym powstawała nauka o wychowaniu jako dyscyplina nienormatywna (Horn, Scarano 2002, s. 335). Systematyczne analizy i rekonstrukcje pojęć sytuowane są w centrum

1 Należy zauważyć, że Brezinka, w przeciwieństwie do zdecydowanej większości „naukowców od wychowania" (niem. Erziehungswissenschaftler) i empirycznych badaczy tego zjawiska, przypisywał duże znaczenie rozwojowi autonomicznej „filozofii wychowania” (niem. Erziehungsphilosophie), która jego zdaniem jest odpowiedzialna za kwestie normatywne dotyczące systemu wychowania i kształcenia. Jednakże błędnie umiejscowił ową filozofię wychowania obok nauki o wychowaniu - a nie w jej wnętrzu (Brezinka 1978, s. 26). 
poszukiwań naukowych, gdy ferowane są oceny moralne i próbuje się je uzasadnić. To sprawia, że konieczne staje się dociekanie znaczeń kategorii moralnych, takich jak na przykład sprawiedliwość, w ich normatywnej funkcji i tłumaczenie ich w sposób racjonalny, nie zaś dogmatyczny. To z kolei wiąże się z odpowiedzią na pytanie, które z tych znaczeń są wiarygodne i mogą stanowić normę dla wywodzącego się z nich działania społecznego. Innymi słowy - które mają szansę na przetrwanie próby uniwersalizacji. Jeżeli natomiast, jak to się stało w omawianym okresie w przypadku nauki o wychowaniu, z góry zaniecha się prowadzenia poszukiwań normatywnych, wówczas można również zaoszczędzić sobie żmudnej pracy analitycznej ${ }^{2}$.

Normatywnie ukierunkowane analizy pojęć są obce bynajmniej nie tylko nauce o wychowaniu. Również najnowsza dziedzina empirycznych badań edukacyjnych z dominującym w niej „ukierunkowaniem na fakty”, które wyraża się między innymi w postulacie „polityki opartej na faktach” (Wössmann 2007, s. 66), pozostaje w znacznej mierze odporna na tego typu analizy. W związku z tym postulatem najczęściej pomija się po prostu to, że fakty mają tylko wówczas sens, gdy są zakotwiczone w schematach pojęciowo-teoretycznych i interpretacyjnych, których nie da się wyprowadzić $z$ tychże faktów. Jeśli się tego nie zrozumie, wówczas łatwo popaść w dobrze znany „mit tego, co dane” (Sellars 1997, s. 13-25). Niektóre dane statystyczne można kojarzyć ze sprawiedliwością edukacyjną tylko wtedy, gdy uprzednio zostaną analitycznie określone cechy i standardy owej sprawiedliwości. Jednak w empirycznych badaniach edukacyjnych najczęściej zakłada się owe cechy arbitralnie. Gdy uwzględni się programowe „ukierunkowanie na fakty” tej gałęzi nauki o wychowaniu, staje się oczywiste, dlaczego daje się z niej wyodrębnić tylko takie cechy omawianej sprawiedliwości, przy których z góry można zakładać, że bez większych trudności da się je statystycznie uzasadnić, jak na przykład zależność karier edukacyjnych od pochodzenia.

Badania empiryczne musi z konieczności poprzedzać rekonstrukcja i analiza cech podstawowych terminów stosowanych w tych badaniach i norm dotyczących

2 Jedną z form takiego odstąpienia od systematycznych poszukiwań analityczno-normatywnych i rekonstruowania znaczeń terminów jest niewątpliwie historyzm, który wydaje się bardzo rozpowszechniony, zwłaszcza wśród wyspecjalizowanych i empirycznie zorientowanych badaczy edukacyjnych. W tym świetle można zrozumieć, dlaczego Ronald Reichenbach i Anna Park uważają, że kształcenie nie jest $\mathrm{w}$ istocie rzeczy terminem logicznym, lecz historycznym (Reichenbach, Park 2014, s. 309). Ich zdaniem uwidocznia się to m.in. w tym, że interpretacje tego pojęcia, a w szczególności zawarte w nim obrazy świata i ludzkiej natury, są naznaczone „politycznym i kulturowym klimatem współczesności” (tamże, s. 310). Moim zdaniem przy takim ujmowaniu ignoruje się po prostu dobrze znane, nieomalże trywialne rozróżnienia między, z jednej strony, genezą i ważnością, to znaczy między logiczną strukturą znaczeń danego pojęcia a jego roszczeniem do bycia ważnym, $\mathrm{z}$ drugiej natomiast, między czynnikami historycznymi, politycznymi, kulturowymi, biograficznymi itp., które oddziaływały na powstanie i rozwój danego pojęcia. 
ich prowadzenia. Jest to klasyczna sfera filozofii. Z tej konstatacji wynika, że szczegółowa analiza terminu „sprawiedliwość edukacyjna” jest zadaniem filozofii kształcenia, która postrzega samą siebie jako gałąź filozofii w ogóle ${ }^{3}$. Równocześnie musi ona znajdować się na poziomie stanu badań i dyskusji metodologicznej prowadzonej $\mathrm{w}$ innych subdyscyplinach filozoficznych, a zwłaszcza w filozofii politycznej, która zajmuje się kategorią sprawiedliwości jako swoim pojęciem centralnym. Tak rozumiana filozofia kształcenia może stać się niezależnym partnerem do współpracy dla empirycznych badań pedagogicznych i dla nauki o wychowaniu - a nie tylko subdyscypliną tej ostatniej.

\section{Sprawiedliwość edukacyjna versus sprawiedliwość zdolności i sprawiedliwość osiągnięć}

Wskazana powyżej filozoficzna analiza pojęcia sprawiedliwości edukacyjnej jest nie tylko warunkiem koniecznym do prowadzenia odpowiednio zróżnicowanych empirycznych badań pedagogicznych. Sama w sobie może również mieć pewne oddziaływanie korygujące na występujące w debacie publicznej błędne interpretacje sprawiedliwości edukacyjnej. Zgodnie z moim stanem wiedzy w prowadzonych do tej pory badaniach pojawiły się co najmniej dwa rodzaje błędnych interpretacji sprawiedliwości edukacyjnej, które trafnie oddają użyte w tytule tego podrozdziału terminy „sprawiedliwość zdolności” (niem. Begabungsgerechtigkeit) i „sprawiedliwość osiągnięć" (niem. Leistungsgerechtigkeit) (Stojanov 2011, s. 113-136).

Jak to już zaprezentowałem $\mathrm{w}$ moich wcześniejszych opracowaniach (np. Stojanov 2013), błędne odczytanie sprawiedliwości edukacyjnej jako sprawiedliwości zdolności czy talentów polega na założeniu, że system edukacyjny będzie sprawiedliwy wówczas, gdy dokona się podziału dóbr edukacyjnych występujących w postaci możliwości kształcenia i potwierdzających je świadectw nie ze względu na pochodzenie uczniów, lecz na ich uzdolnienia, czyli wyjściowe uwarunkowania kognitywne. W związku z tym zakłada się posiadanie przez jednostkę uzdolnień odpowiadających „rozwojowemu potencjałowi intelektualnemu” jeszcze przed rozpoczęciem nauki w szkole ${ }^{4}$.

3 Odnośnie do tego rozumienia zob. Siegel 2012, s. 3-5.

${ }^{4}$ Do zobrazowania takiego rozumienia sprawiedliwości edukacyjnej może posłużyć wymowny przykład ekspertyzy Rady Edukacji (Aktionsrat Bildung) z roku 2007. Radę tę powołało Stowarzyszenie Pracodawców Bawarii (Vereinigung der Bayerischen Wirtschaft). Do jej grona należą najwybitniejsi badacze problematyki oświatowej w Niemczech. We wspomnianej ekspertyzie stwierdza się m.in.: „Relatywnie małe zainteresowanie dzieci i młodzieży niemieckiej zdobywaniem jak najlepszych świadectw nie jest bynajmniej rezultatem niesprawiedliwości edukacyjnej, lecz systemu selekcji. Gdyby tę selekcję usprawiedliwiały same tylko osiągnięcia, to znaczy gdyby mający wystarczające możliwości kognitywne [podkr. K.S.] mieli również zagwarantowany dostęp do oferty kształcenia na wyższym poziomie, to zbędne byłoby mówienie o niesprawiedliwości między poszczególnymi grupami i o marnowaniu zasobów edukacyjnych. 
W nieco innym podejściu do sprawiedliwości edukacyjnej, niż wskazana powyżej sprawiedliwość uzdolnień, uwaga badaczy koncentruje się na wysoko współcześnie cenionej kategorii osiągnięć edukacyjnych, którą niektórzy z nich uważają nawet za jedynie wiarygodne kryterium sprawiedliwego podziału możliwości zakumulowanych w systemie oświatowym. W myśl tego podejścia instytucje edukacyjne są sprawiedliwe wówczas, gdy pozycje zawodowe i możliwości awansu rozdziela się $w$ nich nie według klucza uzdolnień czy potencjałów posiadanych przez jednostki, lecz wyników rzeczywiście osiąganych przez uczniów i uczennice. Często są one określane mianem efektów kształcenia. I tak zdaniem Helmuta Fenda szkoła powinna spełniać swoją funkcję alokacyjną, kierując się wyłącznie osiągnięciami uczniów - bez względu na ich pochodzenie, kolor skóry, płeć, wygląd zewnętrzny czy inne cechy przekazane im genetycznie przez urodzenie. Co więcej, taki sposób postępowania należy zaszczepić w świadomości uczących się jako jedynie sprawiedliwy (Fend 2006, s. 46). Podobnie według wspomnianego już w tym artykule Petera J. Brennera selekcja szkolna jest sprawiedliwa tylko wówczas, gdy dokonuje się jej zgodnie z zasadą ,jakie wyniki - takie szanse" (Brenner 2010, s. 34 i n. oraz s. 103-112).

Do szkicowo przedstawionej powyżej redukcji sprawiedliwości edukacyjnej do sprawiedliwości uzdolnień doszło przede wszystkim wskutek zlekceważenia podejść filozoficznych dyskutowanych we współczesnej debacie na temat sprawiedliwości. John Rawls w swojej klasycznej już teorii sprawiedliwości sformułował zasadę, zgodnie $\mathrm{z}$ którą sprawiedliwe społeczeństwo można rozpoznać po tym, że zabiega się w nim o polepszenie położenia jednostek i grup społecznych znajdujących się w niekorzystnej sytuacji nie tylko z racji pochodzenia, lecz również ze względu na „dary naturalne” (Rawls 1994, s. 121, 336). W związku z tym Rawls postuluje, żeby w szkole więcej uwagi poświęcano uczniom „mniej uzdolnionym niż zdolnym” (tamże, s. 121 i n.). W każdym razie nierówności wynikające z „darów naturalnych" są niezasłużone w takim stopniu, jak te spowodowane przez różnice pochodzenia. Stąd żadną miarą nie można uważać zdolności za ostateczne kryterium sprawiedliwego podziału szans edukacyjnych (tamże, s. 121).

Jednak zwolennicy sprawiedliwości opartej na zdolnościach ignorują aktualny stan dyskusji nie tylko w sprawie teorii sprawiedliwości, lecz również samej kategorii zdolności. Jak przed kilkoma laty sugestywnie przedstawiła Claudia Schumann, współczesną dyskusję na temat zdolności zdominował spór między

Jednak podstawą wspomnianej selekcji nie jest ocena indywidualnego potencjału uczniów. Udział w systemie kształcenia na wyższym poziomie zależy od innych warunków wstępnych niż tylko te natury kognitywnej [podkr. K.S.]. Za szczególnie istotne czynniki ryzyka powodujące brak gotowości do sięgania po propozycje edukacyjne na wyższym poziomie i do kończenia nauki szkolnej świadectwami należy uznać przynależność do warstw czy grup społecznych oddalonych od kształcenia i/lub legitymizujących się pochodzeniem migracyjnym" (Vereinigung der Bayerischen Wirtschaft 2007, s. 12). 
dwoma stanowiskami: statyczno-substancjalnym i dynamiczno-procesualnym (Schumann 2010, s. 5). W pierwszym z nich zdolności są rozumiane jako stałe statyczne, które tuż po urodzeniu, a najpóźniej we wczesnym dzieciństwie ulegają uwarunkowanemu genetycznie zdeterminowaniu. Wokół drugiego stanowiska skupiają się adwersarze tego poglądu, którzy opowiadają się za dynamicznym ujmowaniem zdolności. Ich zdaniem cechy określane mianem zdolności powstają i rozwijają się głównie dzięki społecznym doświadczeniom jednostek (tamże, s. 7-8). To oznacza, że instytucje oświatowe są w stanie „obdarzać” zdolnościami dzieci i młodzież, które się w nich uczą. Jednak dzieje się tak tylko wówczas, gdy bezwarunkowo uznaje się w nich dzieci i młodzież za osoby zdolne do rozwoju. To z kolei zakłada, że nie usiłuje się ich z góry zdyskwalifikować przez odwołanie do tzw. predyspozycji genetycznych.

Zasadniczy błąd myślowy tkwiący w odczytywaniu sprawiedliwości edukacyjnej jako sprawiedliwości osiągnięć polega na tym, że pomija się w nim fakt bycia przez uczniów i uczennice jeszcze niedojrzałymi ludźmi, którzy nie mogą być traktowani w obszarze edukacji jako (w pełni) samodzielni i odpowiedzialni za swoje działania i ich rezultaty. Dlatego też szans zawodowych i możliwości kariery, które są ściśle związane z tokiem kształcenia szkolnego i osiągniętymi w nim wynikami, nie powinno się uważać za zasłużone lub zawinione przez sam podmiot. Szkoły bowiem nie mają do czynienia $\mathrm{z}$ autonomicznymi indywidualnościami, lecz z osobami dorastającymi, u których zdolność do samodzielności dopiero się rozwija. Zadaniem szkoły jest stworzenie sprzyjających warunków do tego rozwoju. Jak trafnie zauważył Martin Heinrich, w merytokratycznym podejściu do sprawiedliwości edukacyjnej usiłuje się przerzucić na barki samych dorastających odpowiedzialność za przebieg i rezultaty ich procesów kształcenia - tymczasem to nie należy do nich (Heinrich 2010, s. 127 i n.).

Na tym tle pojawia się pytanie: jeżeli ani uzdolnienia, ani osiągnięcia nie nadają się do tego, żeby służyć jako miara sprawiedliwego podziału dóbr edukacyjnych, to w takim razie co może nią być? Ale być może to pytanie jest źle postawione. Czy edukacja jest w ogóle dobrem, które da się (roz)dzielić? Ta kwestia jest tematem kolejnego podrozdziału.

\section{Sprawiedliwość edukacyjna poza dystrybucją dóbr}

Nie zagłębiając się w wieloaspektową dyskusję, jaka od dawna toczy się na temat kategorii kształcenia (niem. Bildung), ani w wielowiekową historię tego terminu, można z obu tych źródeł wydobyć wspólny motyw. Jest nim, moim zdaniem, podzielane przez wszystkich przeświadczenie, że kształcenie jest kategorią pedagogiczną oznaczającą proces przechodzenia, albo lepiej rozwoju, do coraz bardziej autonomicznej i zdolnej do autonomii indywidualności (Nida-Rümelin 2013, s. 60). Ta zdolność nie może być jednak przedmiotem jakiejkolwiek dystrybucji czy redystrybucji, ponieważ - w odróżnieniu np. od obdzielania tortem - posiadanie 
większej porcji tej zdolności nie pociąga z konieczności za sobą tego, że inni ludzie muszą mieć jej mniej (Kotzee 2013, s. 343). Przez tę argumentację nie chce się jednak zaprzeczyć faktowi, że oczywiście zinstytucjonalizowane działania na rzecz uzdolnienia kogoś do kierowania się rozumną autonomią wymagają funduszy i zasobów w postaci nauczycieli, książek, pomocy dydaktycznych itp. To właśnie jest punkt, w którym problematyka dystrybucji tych dóbr nabiera dużego znaczenia. Chociaż bowiem edukacja sama w sobie jest dobrem niepodzielnym, to jednak jej rozpoczęcie i prowadzenie zależy od dóbr materialnych, które powinno się rozdzielać sprawiedliwie. Według wspomnianej Rawlsowskiej zasady polepszania pozycji jednostek i/lub grup znajdujących się w niekorzystnej sytuacji sprawiedliwy podział oznacza wezwanie do przeznaczania większych nakładów na rzecz np. uczniów, którzy są marginalizowani z powodu pochodzenia lub stanu zdrowia.

Zapewnienie bazy materialnej jest co prawda warunkiem koniecznym, lecz nie wystarcza do tego, żeby można było mówić o osiągnięciu stanu sprawiedliwości edukacyjnej. Zakładając, że materialne podstawy edukacji zostały zagwarantowane, właściwy proces kształcenia w postaci postępującego rozwoju indywidualnej autonomii jednostki nie zależy już od podziału dóbr materialnych, lecz od jakości interakcji pedagogicznych i relacji społecznych w ramach instytucji edukacyjnych. Zgodnie z tym rozumowaniem system oświatowy może być uznany za sprawiedliwy wówczas, gdy w sposób zinstytucjonalizowany przygotowuje i oferuje takie schematy działania pedagogicznego, które wspierają rozwój autonomii podmiotowej u wszystkich niepełnoletnich uczestników procesu kształcenia.

Z pomocą wzbudzającej współcześnie spore zainteresowanie teorii uznania godności osobowej (niem. Anerkennungstheorie) jesteśmy w stanie zidentyfikować wspomniane powyżej schematy działania sprzyjające rozwijaniu autonomii podmiotowej i konceptualizować je jako normy określające zasady sprawiedliwości edukacyjnej. W ścisły sposób wiąże się to z ujęciem teoretycznym, które od ponad dwóch dekad rozwija Axel Honneth, a które jest ukierunkowane na poszukiwanie odpowiedzi na pytanie: jakie (jakiego rodzaju) muszą być stosunki społeczne, żeby wspierały proces zdobywania autonomii?

W rzeczy samej Honnethowi udało się dotrzeć do wiarygodnej odpowiedzi na powyższe pytanie. Można by ją streścić następująco: stosunki społeczne wspierają autonomię i edukację wówczas, gdy są zgodne $\mathrm{z}$ normami zawartymi w formułach wyrażających empatię, moralny respekt i społeczny szacunek (Honneth 1992, s. 211). Sposoby wyrażania uznania obejmują formy eksponujące zarówno stronę emocjonalną, jak i poznawczą rozwoju indywidualności, przy czym znajdują się one względem siebie w strukturze zależności, którą trafnie oddaje Heglowska figura myślowa: negacja negacji. Empatia, w szczególności ta okazywana dziecku na pierwszych etapach rozwoju jego podmiotowości, ma ogromne znaczenie. Oznacza ona praxis pedagogiczną, polegającą na wczuciu się osoby dorosłej w sposób postrzegania i przeżywania świata przez dziecko oraz na rozpoznawaniu jego potrzeb i pragnień. Odzwierciedlenie tych potrzeb i pragnień przez osoby znaczące jest 
warunkiem koniecznym do tego, żeby (stająca się) indywidualność była w ogóle w stanie odnaleźć dostęp do swojego świata wewnętrznego, co stanowi podstawowy rys osobowości i warunek procesu jej kształtowania.

Wspomniana powyżej druga postać uznania - okazywanie respektu moralnego - nie odnosi się do poszczególnych właściwości czy cech jednostki, lecz do jej abstrakcyjnego statusu, który polega na tym, że jest ona formalnie zrównana ze wszystkimi innymi ludźmi i dysponuje takimi samymi prawami jak oni. W szacunku moralnym nadrzędną rolę odgrywa godność, która przysługuje każdemu człowiekowi i określa jego pryncypialną zdolność do samoodniesienia i autonomicznego działania. Postępując zgodnie z tą normą, należy abstrahować od specyficznych cech danej osoby. Tylko pod tym warunkiem jednostka może rozwinąć w sobie motywację i kompetencje poznawcze, które umożliwią jej zrozumienie perspektywy ogółu. To z kolei pozwoli jej na odpowiedzialne i rzeczowe uczestniczenie $\mathrm{w}$ debacie publicznej.

W końcu społeczny szacunek jest pewnego rodzaju syntezą partykularnego przejawu uznania, jakim jest empatia, i uniwersalnego respektu moralnego. Norma działania pedagogicznego nakazująca okazywanie szacunku społecznego mówi, że w każdym człowieku należy docenić jego specyficzne umiejętności czy możliwości, które mają lub mogą mieć znaczenie z punktu widzenia zbiorowości. Tylko pod warunkiem takiego uznania poszczególne jednostki mogą rzeczywiście rozwinąć umiejętności i potencjały, i je w sobie urzeczywistnić (Honneth 1992, s. 148-211; Stojanov 2006, s. 123-140).

Na tak zarysowanym tle sprawiedliwy system edukacji cechuje się zinstytucjonalizowaniem opisanych powyżej trzech form, a mianowicie empatii, moralnego respektu i szacunku społecznego. To zinstytucjonalizowanie służy jako miara umożliwiająca rozpowszechnienie obowiązkowych standardów działań edukacyjnych. W związku z tym nierówności związane z niejednakowym wyposażeniem instytucji edukacyjnych w sprzęty i inne dobra materialne nie są bynajmniej podstawowym rodzajem niesprawiedliwości tkwiących w systemie edukacji, lecz jest nim lekceważenie potrzeb i doświadczeń uczących się osób. Przejawia się ono w statycznym przyporządkowaniu ich do esencjalistycznie rozumianych talentów i uzdolnień kognitywnych oraz ignorowaniu ich specyficznych potencjałów $\mathrm{i}$ kompetencji. Te zaniedbania, stygmatyzacje i ignorujący stosunek jako symptomy niesprawiedliwości edukacyjnej można jeszcze lepiej opisać, jeżeli odwołamy się do koncepcji epistemic injustice. Temu właśnie będzie poświęcony kolejny rozdział.

\section{Sprawiedliwość uznania a epistemic injustice}

Miranda Fricker w swojej przełomowej książce z 2007 roku pt. Epistemic injustice wyodrębniła dwie zasadnicze formy niesprawiedliwości epistemicznej. Pierwsza wynika z braku dostępu do produkcji wiedzy i możliwości jej pozyskiwania, a przez to - i jest to druga forma tej niesprawiedliwości - do kształcenia. Nazwała je 
odpowiednio: testimonial injustice i hermeneutical injustice (Fricker 2007, s. 1). W obu chodzi o lekceważące praktyki, które utrudniają dostęp do dóbr i, patrząc z punktu widzenia teorii uznania, stanowią mieszaninę braku empatii, dyskryminacji i społecznej pogardy.

$\mathrm{Z}$ testimonial injustice mamy do czynienia wówczas, gdy ignoruje się wiedzę i poglądy osób z powodu ich niskiego statusu społeczno-kulturowego, odmawiając im jednocześnie zdolności do udziału w kolektywnych procesach zdobywania wiedzy (tamże, s. 145). W szkołach zaprzecza się istnieniu tej formy niesprawiedliwości przez to, że nauczyciele i nauczycielki bez empatii reagują na opinie i poglądy wyrażane przez uczniów pochodzących ze społecznie zmarginalizowanych zbiorowości. W Niemczech w szczególny sposób tym zjawiskiem dotknięte są dzieci z rodzin migracyjnych, które po zakończeniu szkoły podstawowej zazwyczaj otrzymują gorsze rekomendacje odnośnie do kolejnego etapu kształcenia niż ich koledzy i koleżanki z klasy pochodzący z rodzimego środowiska, mimo że według niektórych badaczy w testach kompetencyjnych osiągnęli podobne, a niekiedy nawet lepsze wyniki od tych drugich (Baumert $\mathrm{i}$ in. 2001, s. 353).

Zdaniem Mirandy Fricker z hermeneutical injustice stykamy się w sytuacjach, gdy nie opracowano powszechnie akceptowanych pojęć, za pomocą których członkowie grup społecznie marginalizowanych mogliby dać wyraz swoim doświadczeniom i nastrojom. $\mathrm{Z}$ tego rodzaju niesprawiedliwością mamy do czynienia również wówczas, gdy nie werbalizuje się ani nie docenia szczególnych umiejętności i kompetencji posiadanych przez przedstawicieli tych grup (Fricker 2007, s. 6-7). Jak przekonują niektórzy autorzy opracowań o charakterze empiryczno-jakościowym, język, za pomocą którego koncypowane są zajęcia edukacyjne w niemieckich szkołach, służący do opisywania szkolnych doświadczeń nauczycieli, złożony jest prawie wyłącznie z określeń wskazujących na deficyty „uczniów i uczennic z kontekstem migracyjnym". Nie daje on owym uczniom prawie żadnych szans na to, żeby zwerbalizowali zdolności, którymi wielu z nich może się poszczycić, a mianowicie spontaniczne przechodzenie z jednego języka na drugi i tłumaczenie za pomocą różnych pojęć tych samych treści. W kontekście ogólnospołecznym zdolności te są nie tylko niedoceniane, lecz nawet uważane za kulturowy deficyt i dostateczny powód do ektykietowania dysponujących nimi uczniów (Mannitz 2002, s. 319-320; Mannitz, Schiffauer 2002, s. 87-100; Stojanov 2011, s. 131-135, 145-148). Tym sposobem uczniowie ci doświadczają jednocześnie dyskryminacji i społecznej pogardy.

Z pewnością trudno jest - nawet w ogólnym zarysie - przedstawić ideał szkoły, która nie dopuszcza żadnych form epistemic injustice i jednocześnie przezwycięża ignorancję, dyskryminację i społeczną pogardę. Taka szkoła musiałaby uwzględniać (przed-)wiedzę, ideały i doświadczenia uczniów oraz nie tylko tę (przed-)wiedzę, ideały $i$ doświadczenia wplatać w codzienne nauczanie szkolne, lecz również uczynić z nich jego konstytutywny punkt wyjścia. W szkole takiej praca musiałaby się odbywać przy pomocy otwartych, inkluzyjnych i elastycznych programów 
nauczania, które nie byłyby ukierunkowane wyłącznie na obraz świata i język klasy średniej. Przez to stałaby się ona miejscem nauczania umożliwiającego wszystkim dzieciom i młodzieży osiągnięcie autonomii opartej na rozumie, a jednocześnie od strony technicznej dobrze wyposażonym do inicjowania i realizacji tego typu zadań. Z pewnością w Niemczech jesteśmy jeszcze bardzo oddaleni od tego ideału.

\section{Wnioski i perspektywy}

$\mathrm{W}$ artykule starałem się wykazać, że szeroko rozpowszechniona interpretacja sprawiedliwości edukacyjnej jako sprawiedliwości osiągnięć i/lub zdolności jest nie tylko merytorycznie błędna, lecz również pociąga za sobą katastrofalne konsekwencje polityczne i pedagogiczne $\mathrm{z}$ tego powodu, że sama w odniesieniu do uczniów generuje różne formy niesprawiedliwości. Przedstawiona jako alternatywa, bazująca na sprawiedliwości uznania koncepcja sprawiedliwości edukacyjnej, którą w nawiązaniu do terminu Mirandy Fricker można by opatrzyć mianem epistemic justice, pozostawia szereg nierozwiązanych problemów i pytań dotyczących jej przełożenia oświatowo-politycznego i pedagogicznego. Jeżeli zaprezentowane rozumienie sprawiedliwości osiągnięć ugruntowane jest w samym systemie kształcenia, to czy da się przezwyciężyć szeroko rozpowszechnione mniemanie, że system szkolny ma do spełnienia przede wszystkim funkcję selekcyjną i alokacyjną? Jak silnie w kontekście szkolnym oddziałują doświadczenia braku szacunku (respective epistemic injustice) na motywację edukacyjną dzieci i młodzieży pochodzących ze środowisk marginalizowanych? Jakimi zasobami dydaktycznymi i sposobami działania pedagogicznego dałoby się zamienić na praktykę dyrektywę mówiącą o tym, że (przed-)wiedzę, ideały i doświadczenia uczniów należy wplatać w nauczanie szkolne i czynić z nich jego punkt wyjścia? Czy nie należy w szczególny sposób zastosować tej dyrektywy do przedmiotów takich jak religia, etyka i filozofia, które wydają się bardziej otwarte na codzienne doświadczenia uczniów i wiedzę z nich wynikającą niż przykładowo przedmioty przyrodnicze? Znalezienie odpowiedzi na te i tym podobne pytania wymaga dalszych studiów i analiz pojęciowych, empirycznych i dydaktycznych.

\section{Z języka niemieckiego przetłumaczył Dariusz Stępkowski}

\section{Bibliografia}

Baumert J. i in. (Deutsches PISA - Konsortium) (2001). PISA 20oo. Basiskompetenzen von Schülerinnen und Schüler im internationalen Vergleich. Opladen: Leske + Budrich.

Brenner P. J. (2010). Bildungsgerechtigkeit. Stuttgart: Kohlhammer.

Brenner P.J. (2009). Bildungsgerechtigkeit aus Sicht der Bildungswissenschaft. W: Deutscher Lehrerverband (red.). Bildungsgerechtigkeit: Fachtagung 2008 
(Dokumentation), dostępny na: www.lehrerverband.de/Bildungsgerechtigkeit. pdf (otwarty 7.01.2016), s. 28-43.

Brezinka W. (1978). Metatheorie der Erziehung. München und Basel: Reinhardt.

Brezinka W. (1968). Von der Pädagogik zur Erziehungswissenschaft. Vorschläge zur Abgrenzung. „Zeitschrift für Pädagogik” nr 14, s. 435-454.

Fend H. (2006). Neue Theorie der Schule. Einführung in das Verstehen von Bildungssystemen. Wiesbaden: VS Verlag.

Fricker M. (2007). Epistemic injustice. Power and the ethics of knowing. Oxford: Oxford University Press.

Gallie W.B. (1964). Philosophy and the historical understanding. London: Chatto $\&$ Windus.

Göhler G., Iser M., Kerner I. (2004). Zur Einführung. W: tychże (red.). Politische Theorie. 22 umkämpfte Begriffe zur Einführung. Wiesbaden: Verlag für Sozialwissenschaften, s. 7-10.

Heinrich M. (2010). Bildungsgerechtigkeit - Zum Problem der Anerkennung fragiler Bildungsprozesse innerhalb neuer Steuerung und demokratischer Governance. W: Aufenanger S., Hamburger F., Ludwig L., Tippelt R. (red.). Bildung in der Demokratie. Beiträge zum 22. Kongress der Deutschen Gesellschaft für Erziehungswissenschaft. Opladen: Budrich, s. 125-144.

Honneth A. (1992). Der Kampf um Anerkennung. Zur moralischen Grammatik sozialer Konflikte. Frankfurt a. M.: Suhrkamp Verlag.

Horn Ch., Scarano N. (2002). Einleitung zum V. Kapitel. W: Horn Ch., Scarano N. (red.). Philosophie der Gerechtigkeit. Texte von der Antike bis zur Gegenwart. Frankfurt a. M.: Suhrkamp, s. 335-344.

Kotzee B. (2013). Educational justice, epistemic justice, and leveling down. „Educational Theory” nr 4, s. 331-349.

Mannitz S. (2002). Auffassungen von kultureller Differenz: Identitätsmanagement und diskursive Assimilation. W: Schiffauer W., Baumann G., Kastoryano R., Vetrovec S. (red.). Staat - Schule - Ethnizität. Politische Sozialisation von Immigrantenkindern in vier europäischen Ländern. Münster: Waxmann, s. 255-320.

Mannitz S., Schiffauer W. (2002). Taxonomien kultureller Differenz: Konstruktionen der Fremdheit. W: Schiffauer W., Baumann G., Kastoryano R., Vetrovec S. (red.). Staat - Schule - Ethnizität. Politische Sozialisation von Immigrantenkindern in vier europäischen Ländern. Münster: Waxmann, s. 67-100.

Müller K., Ehmke T. (2013). Soziale Herkunft als Bedingung der Kompetenzentwicklung. W: Prenzel M., Sälzer Ch., Klieme E., Köller O. (red.). PISA 2012. Fortschritte und Herausforderungen in Deutschland. Münster: Waxmann, s. 245-274.

Nida-Rümelin J. (2013). Philosophie einer humanen Bildung. Hamburg: Körber-Stiftung. 
Paschen H., Wigger L. (1992). Zur Analyse pädagogischer Argumentationen. Bericht des Forschungsprojekts „Bielefelder Katalog pädagogischer Argumente”. Weinheim: Deutscher Studien Verlag.

Rawls J. (1994). Teoria sprawiedliwości. Warszawa: PWN.

Reichenbach R., Park A. (2014). Über die „Wut des Verstehens”. „Erwögen-Wissen-Ethik" nr 2, s. 309-311.

Schumann C. (2010). Projektantrag „Begabung” als Diskurstopos in Politik, Medien und Wissenschaft. Unveröffentlichtes Manuskript.

Sellars W. (1997). Empiricism and the philosophy of mind. Cambridge: Harvard University Press.

Siegel H. (2012). Introduction: philosophy of education and philosophy. W: tenże (red.). The Oxford handbook of philosophy of education. Oxford: Oxford University Press, s. 3-8.

Stojanov K. (2006). Bildung und Anerkennung. Soziale Voraussetzungen von Selbstentwicklung und Welt-Erschließung. Wiesbaden: Springer VS.

Stojanov K. (2011). Bildungsgerechtigkeit. Rekonstruktionen eines umkämpften Begriffs. Wiesbaden: Springer VS Verlag.

Stojanov K. (2013). Bildungsgerechtigkeit als Anerkennungsgerechtigkeit. W: Dietrich F., Heinrich M., Thieme N. (red.). Bildungsgerechtigkeit jenseits von Chancengleichheit. Theoretische und empirische Ergänzungen und Alternativen $z u$,PISA'. Wiesbaden: Springer VS, s. 57-70.

Vereinigung der Bayerischen Wirtschaft (red.). (2007). Bildungsgerechtigkeit. Jahresgutachten 2007. Wiesbaden: VS Verlag.

Wössmann L. (2007). Letzte Chance für gute Schulen. Die 12 großen Irrtümer und was wir wirklich ändern müssen. München: Zabert Sandmann Verlag.

\title{
EDUCATIONAL JUSTICE AS A CATEGORY OF PHILOSOPHY OF EDUCATION
}

\begin{abstract}
In this paper I first argue that we can reconstruct the norms of educational justice only if we understand and treat it as a category of the Philosophy of Education. In the second part of the paper I undertake such reconstruction which outcomes could be summarized as follows: it is wrong to interpret educational justice in meritocratic terms, that is, as fair distribution of educational resources and opportunities according to achievements and/or assumed talents of the students. Moreover, I argue that it is generally incorrect to spell out educational justice as distributive justice. Instead, educational justice should be understood as relational justice. According to that understanding, educational institutions and pedagogical interactions are just, if they embody the recognition forms of empathy, moral respect and social esteem. This claim becomes particularly plausible, if we link it to the recent philosophical discussion on epistemic justice.
\end{abstract}


Keywords: educational justice, philosophy of education, empathy, moral respect, social esteem

Krassimir Stojanov - doktor habilitowany, profesor Katholische Universität Eichstätt-Ingolstadt (KUE-I, Niemcy), kierownik Katedry Pedagogiki Systematycznej/Filozofii Edukacji na Wydziale Filozoficzno-Pedagogicznym KUE-I. Publikacje autorskie: Bildung und Anerkennung. Soziale Voraussetzungen von Selbstentwicklung und Welt-Erschließung (2006), Bildungsgerechtigkeit. Rekonstruktionen eines umkämpften Begriffs (2011). Adres e-mail: krassimir.stojanov@ku.de. 